\title{
夏季夜間における山麓冷気流の市街地熱環境緩和効果に関する研究 COOLING EFFECTS ON A BUILT-UP AREA CAUSED BY COLD AIR DRAINAGE ON SUMMER NIGHT
}

\author{
竹 林 英 樹*1，森 山正 和*2，芝 池 英 樹*3 \\ Hideki TAKEBA YASHI, Masakazu MORIYAMA and Hideki SHIBAIKE
}

\begin{abstract}
The air temperature distribution in the built-up area facing the mouth of a valley was investigated using both measurements and calculations. Surface temperature was kept higher than air temperature at every time in the night, and it is thought that the cold air drainage flowing into the built-up area has the capability that cools the built-up area. Calculations indicated that air temperature decreased in the riverside area and increased in the southern built-up area. This tendency was in good agreement with measurements taken in the present study. Since sensible heat flux had positive and negative values as a result of calculating the surface heat budget according to land uses, it was indicated to be the cases where the cold air drainage supplies both cold air to the built-up area and hot air to the forest area. From calculation in consideration of the altitude distribution, air temperature in the built-up area became low as compared with the case where altitude is not taken into consideration. It is thought that the slope of geographical feature is promoting the drainage of cold air.
\end{abstract}

Keywords: Cold Air Drainage, Observation, Summer Night 冷気流，実測，夏季夜間

1、はじめに

神戸のように山に面して発達した都市では, 夏季夜間に山の森林 部で放射冷却により生成された冷気が斜面に沿って市街地内へ流下 してくるため, 市街地内の熱環境が緩和される可能性がある。その 効果の定量化を目的として，著者らは神戸のように谷口が市街地に 面した都市における，冷気流による市街地気温低下効果の可能性に ついて検討を行い，谷において集積された冷気が流出してくるため に，比較的大きな市街地気温の低下が期待できるが，その可能性は 広域海陸風が弱い条件に限られ，山から離れるとその可能性は低く なり, 広域の風が強くなると冷気流は吹き消されるという結論を得 $た^{1), 21}$.ここで, 広域海陸風とは大阪平野と大阪湾との熱バランス により吹く海陸風を意味する.

本報では，冷気流が流出してくる市街地内において，実測調查と 拡散モデルにより気温，風分布に関する検討を行い，冷気の流出が 市街地内の夜間の熱環境に及ぼす影響について考察する。

冷気流と市街地気温分布に関する解析には，ドイツのシュツット ガルトの事例が参考になる．ドイツは高緯度にあるため，その環境 政策は夏の暑さに関するものよりむしろ大気污染対策を中心とした ものであり，特に夜間から早朝にかけての逆転層と関連している. シュツットガルト市は盆地内に位置するため夜間に冷気湖が形成さ れる，周辺の丘陵森林部で生成された冷気が谷間に集積し，その泠
気が市内中央駅付近にまで到達するという。そして条件の良い夜間 には，1つの谷で生成された冷気が丘の高さを超えて反対側の谷に まで影響を及ぼすこともあると説明される ${ }^{3)}$.

本研究で対象とするような斜面地域においては, 放射冷却により 冷却された地表面や屋根面などと比較すると上流から流入してきた (冷) 気流が必ずしも低温ではない可能性もある。しかし一般的に は，市街地は熱容量の大きな材料で構成されているため夜間も高温 に保たれている可能性が高いと考えられる，そこで，本研究では市 街地へ流入してくる冷気流と建物などの市街地内構成物との熱交換 過程についても併せて検討を行い，冷気流が市街地の熱環境へ及ぼ す影響について考察する．併せて，地形（標高分布）の影響を考虑 する場合としない場合についても比較検討する.

\section{2. 実測調查による検討}

\section{1 実測調查の概要}

測定対象地域（図 1）は，京都市北区賀茂川上流地域の南北約 4 $\mathrm{km}$ ，東西約 $3.5 \mathrm{~km}$ にわたる市街地である．北西に谷口があり賀茂川 が南東へ向かって流下している，市街地は北，東，西の山に囲まれ ているが，東西の山には大きな谷はない.

この地域を 4 つのルートに分けて移動測定を行った．各ルートで は 10 地点において測定を行い，各地点では最低 5 分停止した後に測
*1 神戸大学工学部建設学科 助手 ・ 博士 (工学)

*2 神戸大学工学部建設学科 教授. 工博

*3 京都工芸繊維大学工芸学部造形工学科 助教授 $\cdot$ 工博
Research Assoc., Dept. of Arch. \& Civil Eng., Faculty of Eng., Kobe Univ., Dr. Eng. Prof., Dept. of Arch. \& Civil Eng., Faculty of Engineering, Kobe University, Dr. Eng. Assoc. Prof., Dept. of Arch. \& Design, Faculty of Eng. \& Design, Kyoto Inst. of Tech., Dr. Eng. 


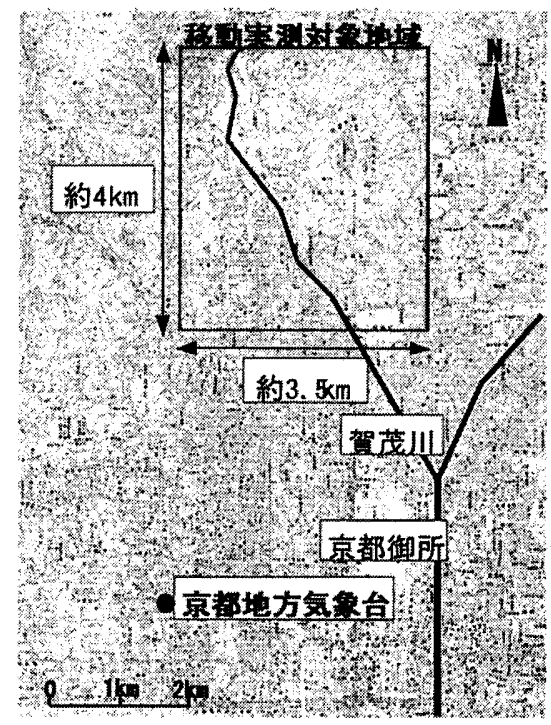

図 1 測定対象地域

\begin{tabular}{c|c} 
表 1 測定時刻 & $(2001$ 年 8 月 $6 \sim 9$ 日の夜間 $)$ \\
\hline 日 & 時刻 $*$ \\
\hline $6 \sim 7$ 日 & 19 時, 22 時, 1 時, 4 時 \\
$7 \sim 8$ 日 & 20 時, 23 時, 2 時, 5 時 \\
$8 \sim 9$ 日 & 19 時, 22 時, 1 時, 4 時 \\
\hline
\end{tabular}

*この時刻前後の約 90 分間で 1 回の測定を行った.

定データを取得した，従って，1回の測定には移動時閒を含めて約 90 分を要した．対象地域内の上流側と下流側に位置する小学校 2 校 において，移動測定の時間補正を行うために定点測定を実施した.

測定方法は，延ばした際に約 $4 \mathrm{~m}$ 程度となる釣り竿の先端にサー ミスタと風船を設置して地上 $4.0 \mathrm{~m}$ における気温と風向の測定を 行った．地上 $1.5 \mathrm{~m}$ だけでなく $4.0 \mathrm{~m}$ の気温を測定する目的は， $1.5 \mathrm{~m}$ の気温は直下の道路面の影響を強く受けるのに対し， $4.0 \mathrm{~m}$ の気温 は道路による直接的な影響が少なく空間分布の考察に適すると考 えたからである．風速は各地点で風向を確認した後に 1 秒毎の专 ンプリングを 10 回行った平均值を記録した．突風の条件での測定 は避けたが，測定時刻によるばらつきについての補正は行ってい ない. 図 2 に移動測定の概要を示す.

測定期間は，2001 年 8 月 $6 〜 9$ 日の夜間である. 表 1 に示す時刻 の前後 90 分をかけて測定を行った。降水量は 7 日 18 時に $5 \mathrm{~mm}, 19$ 時に $10 \mathrm{~mm}$ を記録したのみであるが（京都地方気象台），雲量は期間

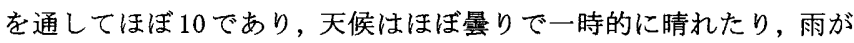
降ったりする条件であった，測定期間中では 3 日目（8〜9日）が, 日中の気温が上昇し，夜間の気温低下量も大きい日であり，典型的 な夏の晴天日に近い条件であったと言える.

\section{2 観測結果}

以下の解析では，測定期間中で最も気象条件に恵まれた 3 日目 $(8$ 〜 9 日) の結果を主な検討対象とする. 1 回の移動測定に約 90 分を 要したため, 上流側と下流側の小学校 2 校での定点連続測定結果を 基に，測定対象領域も 2 ブロック（上流側と下流側）に分割し，移 動測定結果を定点観測の結果の時刻変化を利用して線形補間によ り正時（測定期間中の中央）の值に補正した.

\section{1 ) 地上 $4.0 \mathrm{~m}$ の気温と $1.5 \mathrm{~m}$ の気温及び地表面温度の関係}

図 3 に 8 月 8 日 19,22 時, 9 日 $1 ， 4$ 時における地上 $4.0 \mathrm{~m}$ の気温

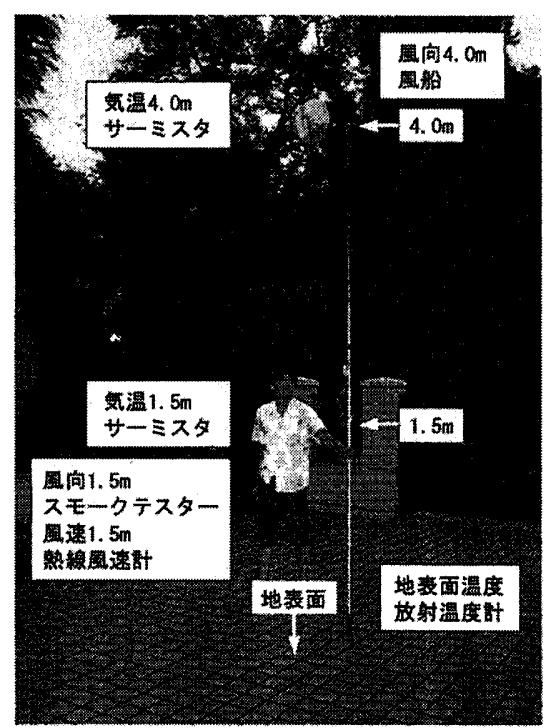

図 2 移動測定の概要

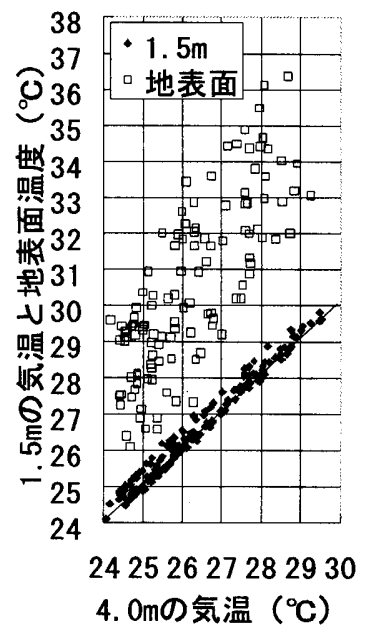

図 3 地上 $4.0 \mathrm{~m} の$ 気温と $1.5 \mathrm{~m}$ の気温及び地表面温度の関係 (2002 年 8 月 8 日 19,22 時，

9 日 1,4 時)
図 4 地上 $4.0 \mathrm{~m}$ の気温亡

$1.5 \mathrm{~m}$ の気温の関係

(2001年 8 月 8 日 22 時)

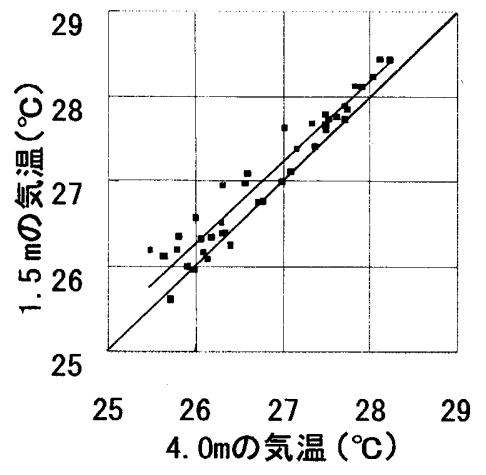

と $1.5 \mathrm{~m}$ の気温及び地表面温度の観測結果の関倸を示す。市街地内 の構成物（建物，道路など）が日射を蓄熱する影響で地表面温度 （すべてアスファルト道路面）がどの時間帯においても気温より高 く保たれており，市街地一流入している椧気流は文字通り市街地 を冷却する能力を持っていると考えられる。この時の地表面温度 と気温の温度差を泠却ポテンシャルと考えると，その量は夜間を

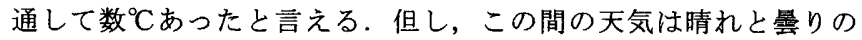
混在した条件であったため, 放射冷却量（夜間放射）は若干少な く放射による地表面温度の低下量は少ない条件であったと言える。

図 4 に 8 月 8 日 22 時における地上 $4.0 \mathrm{~m}$ の気温と $1.5 \mathrm{~m}$ の気温の 観測結果の関係を示す. $1.5 \mathrm{~m}$ での值が $4.0 \mathrm{~m}$ での値よりも $0.2 \sim 0.3$ ${ }^{\circ} \mathrm{C}$ 程度高くなっており, 他の時間帯においても上下の測定点間での この関倸はほぼ同じであった。この原因は，1.5m付近の気温は日射 を蓄熱した地表面や周囲建物のより局所的な影響を受けて高温に なっていたためであると考えられる. それに対し， $4.0 \mathrm{~m}$ の気温は地 表面や周囲建物の局所的な影響だけでなく, 冷気流などの周辺か ら流入する空気の影響も含んだ気温になっていると考えられる。 
従って, 冷気流の市街地気温へ及ぼす影響について検討を行う 本研究の解析においては, 観測結果に対するより局所的要因によ

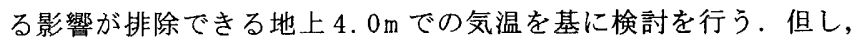
測定方法の都合で地上 $4.0 \mathrm{~m}$ における風速の測定は行われていない

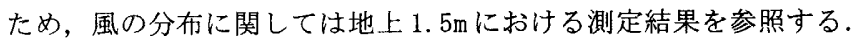

\section{2 ）気温分布と風ベクトル分布}

観測結果に基づいて作成した地上 $4.0 \mathrm{~m}$ の気温分布と地上 $1.5 \mathrm{~m}$ の

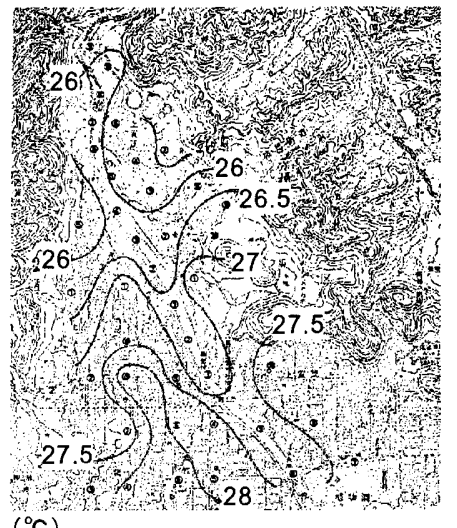
$\left({ }^{\circ} \mathrm{C}\right)$

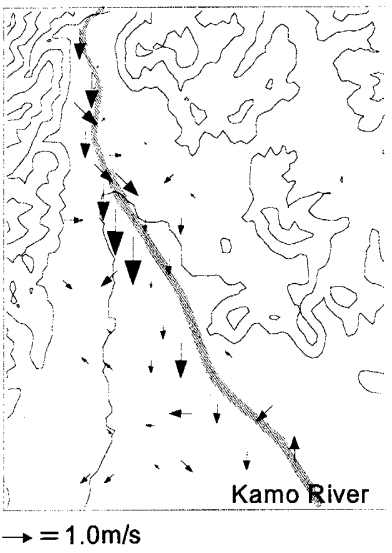

図 5 気温と風の観測結果 (8月 8 日 22 時)

左 : 気温分布 (地上 $4.0 \mathrm{~m})$, 右 : 風ベクトル分布 (地上 $1.5 \mathrm{~m})$

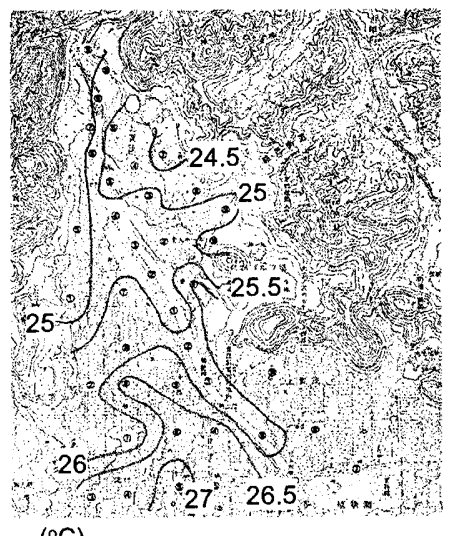

$\left({ }^{\circ} \mathrm{C}\right)$

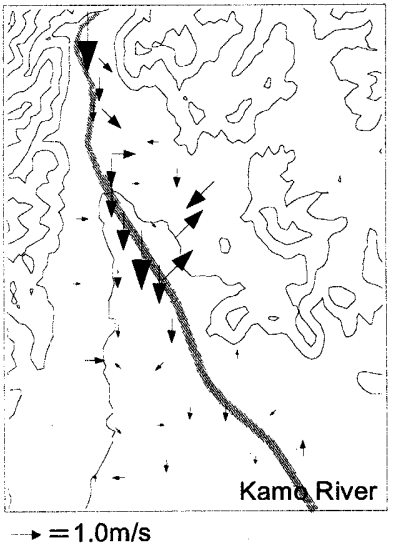

図 6 気温と風の観測結果（8月 9 日 1 時）

左：気温分布（地上 $4.0 \mathrm{~m}$ ), 右: 風ベクトル分布（地上 $1.5 \mathrm{~m} ）$

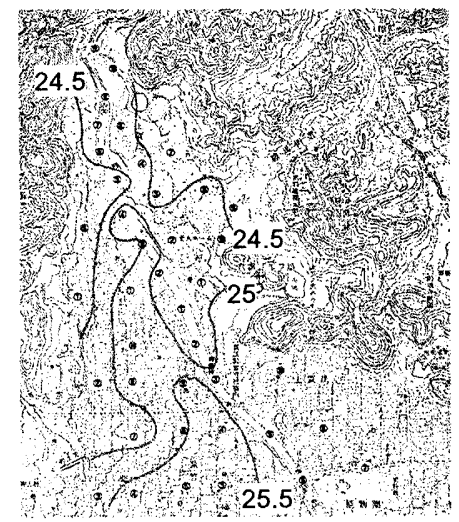

$\left({ }^{\circ} \mathrm{C}\right)$

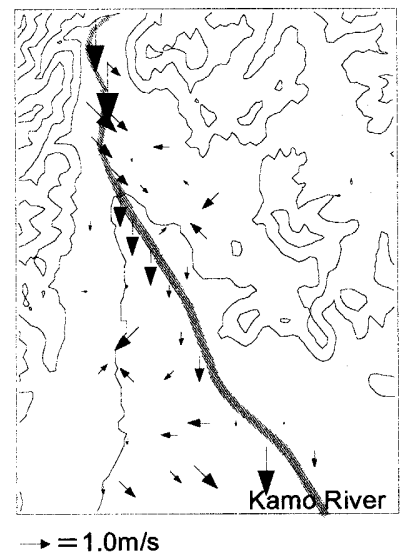

図 7 気温と風の観測結果（8月 9 日 4 時）

左: 気温分布 (地上 $4.0 \mathrm{~m}$ ), 右: 風ベクトル分布（地上 $1.5 \mathrm{~m} ）$

風ベクトル分布を図 5, 6,7 に示す. 気温は時間とともに徐々に低下 している. 4 時の気温分布では対象地域全体において気温差がほと んどなくなっており, 泠気が領域内を満たしていると言える。気 温分布のパターンでは, 時刻による変化があまり見られず, 川沿 いでは周辺市街地と比較して常に低温となっている，風べクトル の分布より, 川沿いにおける北風の風速が周辺市街地と比較して 大きくなっているため，川沿い地域に冷気流が流れ込み易くなっ ており, 泠気流の流入に伴う気温低下の効果が大きく表れている と考えられる. 市街地内でも対象地域南西側で常に低温になって いる地点があり，公園が隣接しているためであると推測される.

\section{3. 拡散モデルによる検討}

\section{1 解析概要}

移動実測の対象地域とほぼ同じ領域の京都市北区賀茂川上流地域 の南北約 $3.75 \mathrm{~km}$, 東西約 $2 \mathrm{~km}$ にわたる谷口周辺市街地が対象である (図 11 参照).この領域を $50 \mathrm{~m} \times 50 \mathrm{~m} \times 3 \mathrm{~m}$ メッシュで分割し, 格子 数は $75 \times 40 \times 50$ 個である。

乱流モデルには標準 $\mathrm{k}-\varepsilon$ 型 2 方程式モデルを用い, 観測を行った 2001 年 8 月 9 日 1 時を対象日時として計算を行った ${ }^{42}$. 地表の境 界条件の，地表面温度は観測結果に基づき空間分布は補間により作 成した. 粗度分布については細密数值情報に基づいて作成した。 な お，各土地利用のカテゴリーに対する設定值については文献をを参 考に与えた. 地表面のフラックスは $\mathrm{z}_{0}$ 型の対数則を用いて与えた. 流入の境界条件は対象領域に面寸る谷の中の泠気の集積過程を浅 水方程式モデルにより計算した結果に基づいて $\mathrm{k} ， \varepsilon$ とともに対数 則を仮定して与えた ${ }^{2)}$. 気温については一様な値を与えた。 上空, 流出，側面の境界は各要素を勾配なしとし，初期条件については， 風は浅水方程式モデルの計算結果より $\mathrm{k}, \varepsilon$ とともに対数分布で作 成し，気温については領域全体に一様な值を仮定した。

図 8 に境界条件に用いた地表面温度分布を，図 9 に粗度分布を示 す. 地表面温度は, 谷口に近い賀茂川西側の宅地造成地において 高温であった。この原因は, 造成地であるためアスファルト地表 面に対して影になる建築物等が無く，日射の蓄熱量が大きかった ためであると考えられる。河川の表面温度は対象領域内 5 地点で 測定した表面温度データを平均して 23.3 ${ }^{\circ} \mathrm{C}$ (周囲より低温) と設定した。図 10 に

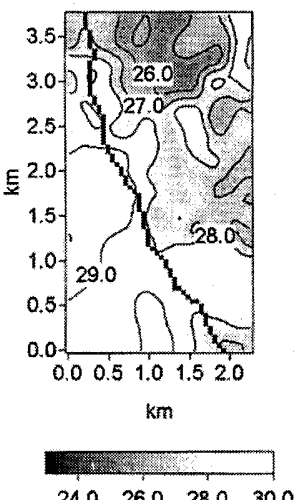

$\begin{array}{llll}24.0 & 26.0 & 28.0 & 30.0\end{array}$

図 8 境界条件の 地表面温度分布 $\left({ }^{\circ} \mathrm{C}\right)$

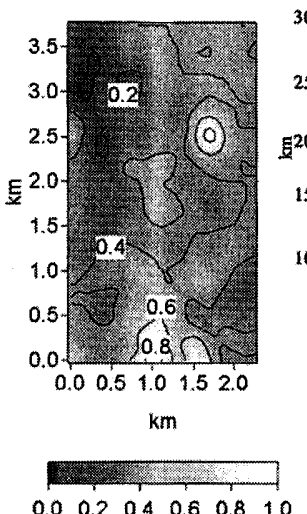

図 9 境界条件の 粗度分布 (m)

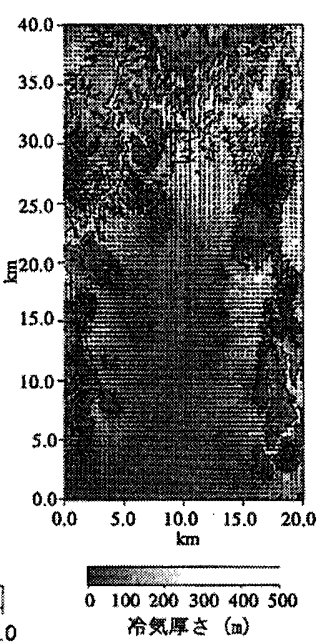

图 10 境界条件に用い る浅水方程式モデルの 結果（枠内が計算領域） 
流入境界条件に用いた浅水方程式モデルによる計算結果を示す、 計算対象領域に対しては北側の谷間から泠気が流出してくる結果 になっている。

\section{2 計算結果}

地表面温度を固定し，一定の流入風を与え続ける定常計算であ るため, 計算を続けると地表面との熱交換により, 地表面温度を 低く設定した森林部ではますます気温が低下し, 地表面温度を高 く設定した市街地部では気温が上昇する傾向になる。このとき, 現 実には非定常の条件であるため，地表面温度も変化するはずであ る. 従って, 本研究においては, 流入風が地表面温度とある程度 熱交換を行った後の計算結果を準定常な状況であると仮定し, 以 下での考察の対象とする，ちなみに計算開始後 150 秒（この時点を 準定常と仮定）の計算結果を採用した．地表面温度分布を固定し て与えた点について検討するために次節において, 地表面の境界 条件として土地利用別に熱収支の計算を行った場合の計算を実施 する，なお，計算領域内の標高分布については考慮できていない が，測定対象とした市街地部はほぼ平坦な地形であった。

\section{1) 気温の水平分布}

地上 $4.0 \mathrm{~m}$ の観測結果より作成した 2 次元平面での気温分布と地 上 $4.5 \mathrm{~m}$ での計算結果による気温分布を図 11 に示す。計算結果は, 鈆直方向の格子間隔が地表付近で $3.0 \mathrm{~m}$ であるため, 地上 $4.0 \mathrm{~m}$ に最 も近い $4.5 \mathrm{~m}$ （地上第 2 セル）での值を示す.

計算結果は地表面温度分布の影響を受けて, 川沿いの地域におい て気温が低下し，南部の密集市街地において高温となっている。こ の傾向は，観測結果とよく一致している．計算結果の対象領域内で

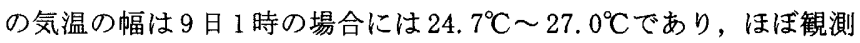
結果と一致している、計算結果における対象領域右上（北東部）の 高温部分は京都産業大学付近であり, 粗度が大きく設定されている 関係で，地表面との熱交換が盛んとなり気温は高温になっている.

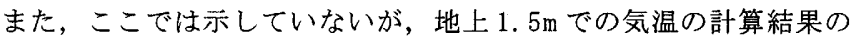
幅は $24.4^{\circ} \mathrm{C} \sim 27.7^{\circ} \mathrm{C}$ となり, 観測結果と同様に地上 $1.5 \mathrm{~m}$ の気温は $4.0 \mathrm{~m}$ の気温に比べて $0.3^{\circ} \mathrm{C} \sim 1.1^{\circ} \mathrm{C}$ ぼ゙高くなっていた.

\section{2 ）風ベクトルの水平分布}

地上 $1.5 \mathrm{~m}$ の観測結果より作成した 2 次元平面での風ベクトル分 布と地上 $1.5 \mathrm{~m}$ での計算結果による風ベクトル分布を図 12 に示す. 計算結果の風ベクトル分布はすべて北風で，計算領域上部（北側） の谷口付近で風速が大きく, 下部（南側）の密集市街地付近でやや 小さくなっている. しかし，ほぼ一様な分布をしており, 観測結果 に見られるようなばらつきは見られない。

地上 $1.5 \mathrm{~m}$ の観測結果は建築物等の障害物によって風が遮られる などの局所的な影響を受けた風ベクトル分布となっているのに対し， 計算結果はある程度なめらかな粗度分布に応じた平均的な風べクト ル分布になっていると言える.

\section{3 地表面熱収支を考慮した計算}

前節では, 地表面の境界条件として観測結果より作成した地表面 温度分布を与えて計算を行ったが，実際には上流の谷間などから市 街地一流入してきた空気と地表面との間で熱交換が行われ，時々 刻々地表面温度と気温が変化している。計算領域内において，日 射の蓄熱効果により高温に保たれているコンクリートやアスファ ルトなどの人工被覆面からは大気に対して顕熱を供給していると

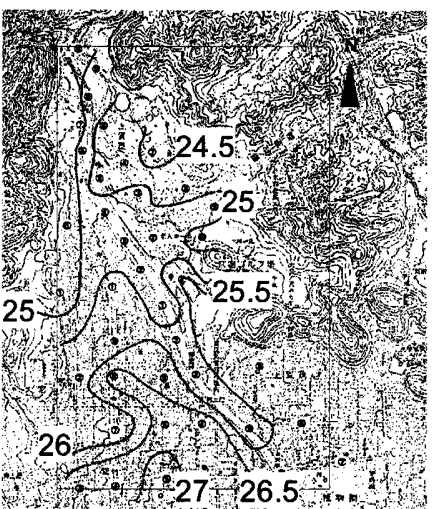

$\left({ }^{\circ} \mathrm{C}\right)$

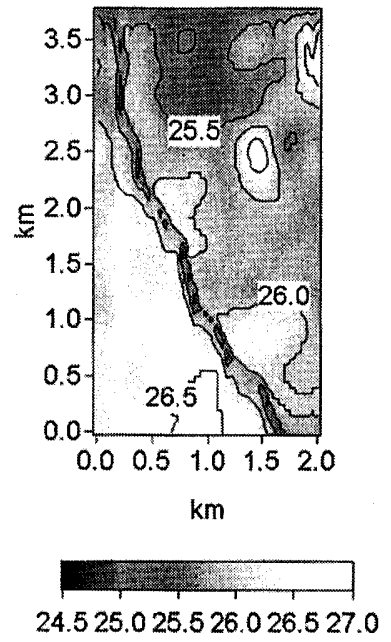

$\left({ }^{\circ} \mathrm{C}\right)$
図 11 気温の観測結果と計算結果 (2001 年 8 月 9 日 1 時) 左：地上 $4.0 \mathrm{~m}$ の钼測結果, 右 : 地上 $4.5 \mathrm{~m}$ での計算結果
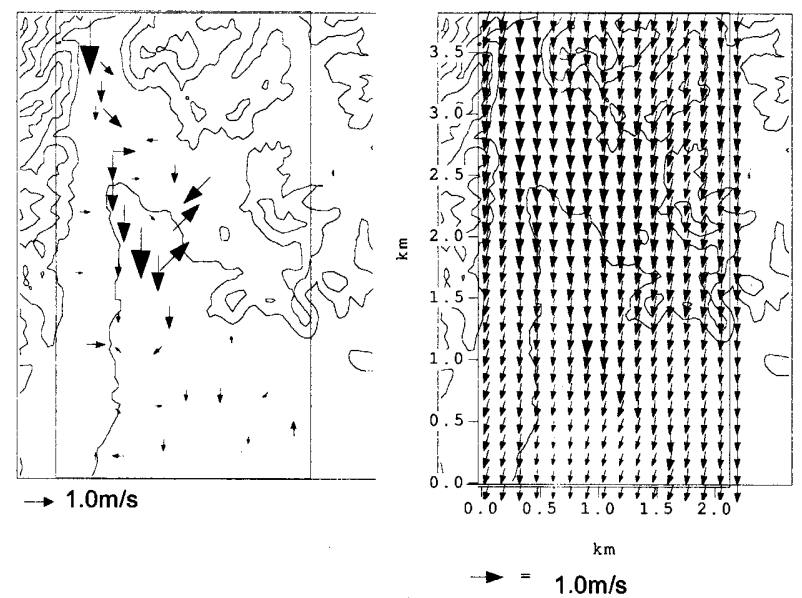

図 12 風ベクトルの钼測結果と計算結果（2001 年 8 月 9 日 1 時） 左：地上 $1.5 \mathrm{~m}$ の钼測結果, 右 : 地上 $1.5 \mathrm{~m}$ での計算結果
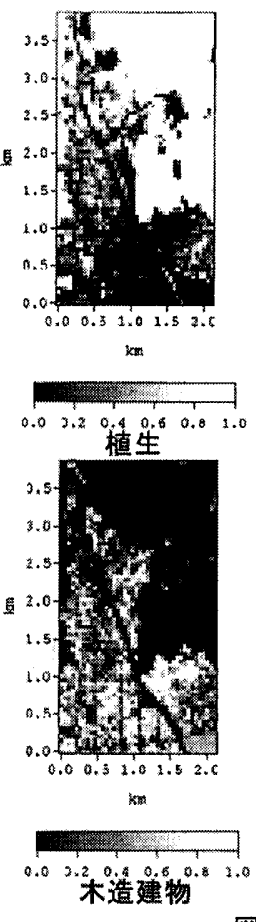
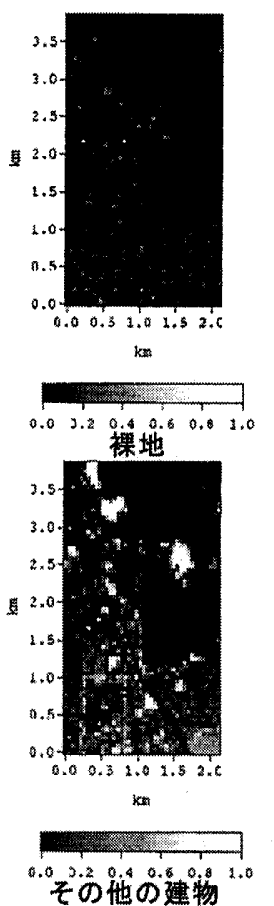

その他の选物
図 13 カテゴリー別被覆率
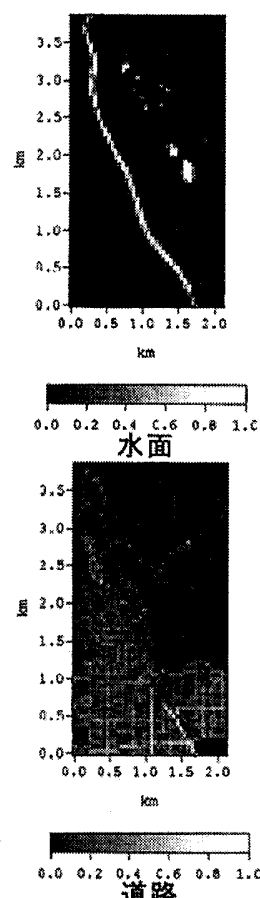


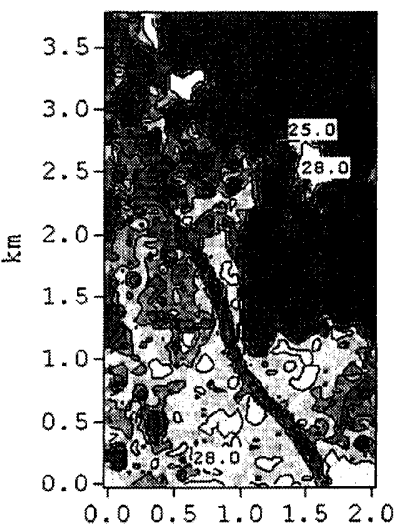

$\mathrm{km}$

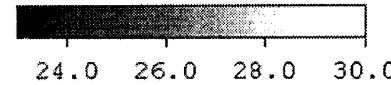

図 14 地表面温度分布 $\left({ }^{\circ} \mathrm{C}\right)$

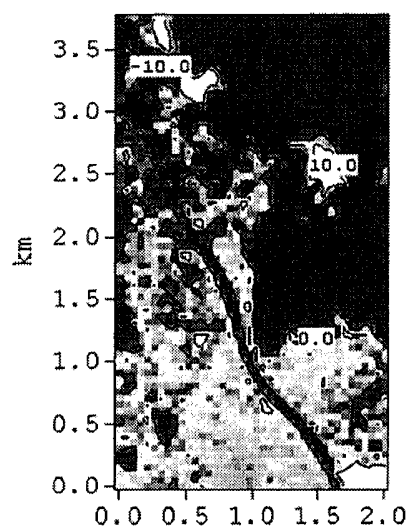

$\mathrm{km}$

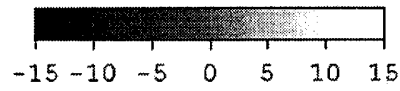

図 15 䫓熱フラックス $\left(\mathrm{W} / \mathrm{m}^{2}\right)$

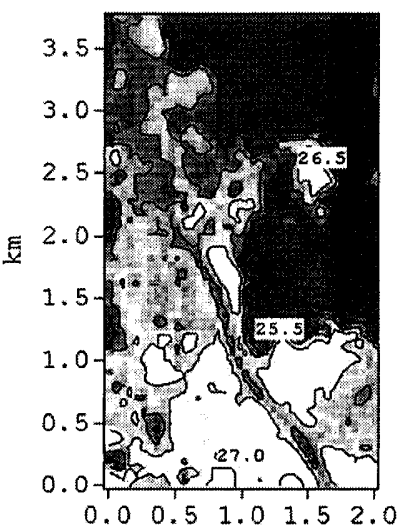

$\mathrm{km}$

24.525 .025 .526 .026 .527 .0

図 16 地上 $1.5 \mathrm{~m}$ の気温分布 $\left({ }^{\circ} \mathrm{C}\right)$ 図 17 地上 $1.5 \mathrm{~m}$ の風分布 $(\mathrm{m} / \mathrm{s})$ （標高分布を考慮しない場合）

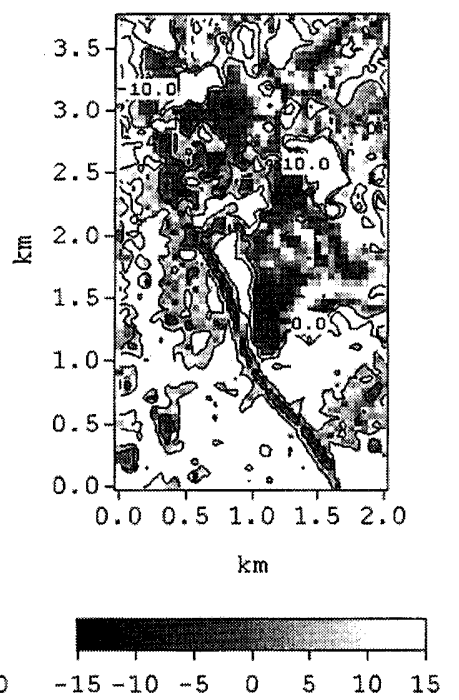

図 19 顕熱フラックス $\left(W / \mathrm{m}^{2}\right)$

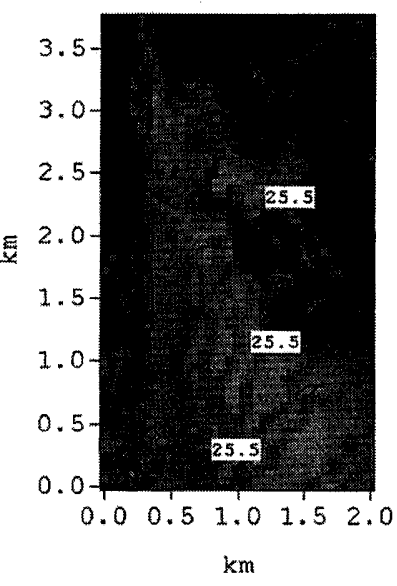

24.525 .025 .526 .026 .527 .0

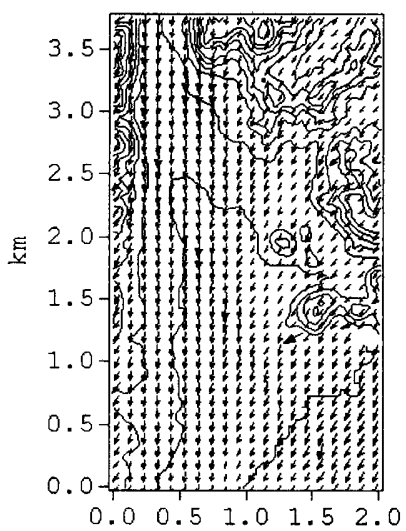

$\rightarrow=1.00^{\mathrm{km}}$
（背景に標高のコンターを示す）

（標高分布を考慮する場合）

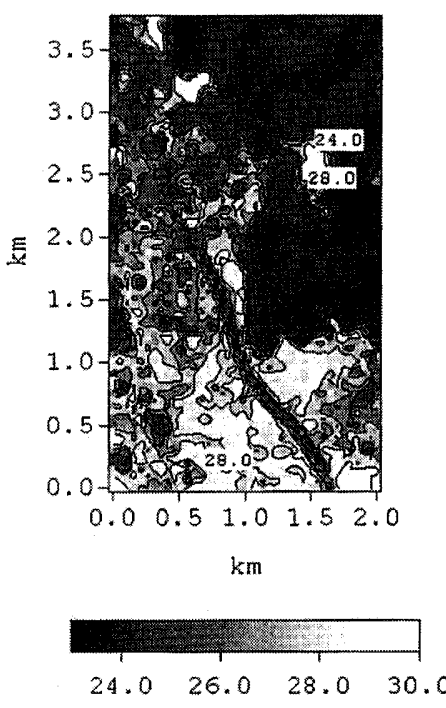

図 18 地表面温度分布 $\left({ }^{\circ} \mathrm{C}\right)$
考えられるが，緑地などの自然地表面では逆に空気から地表面へ 顕熱が供給されている可能性がある。従って，ここでは典型的な 地表面での熱収支を考虑した地表の境界条件を用いた場合の計算 を行い，地表面における熱収支を考慮した市街地気温分布の考察 を行う。

\section{1) 地表面熱収支モデル}

ここでは 16 分類されている細密数值情報を, 植生, 裸地, 水面, 木造建物, その他の建物, 道路, の6つのカテゴリーに集約し，そ れぞれのカテゴリーに対して, 物性值を仮定した. 分類されたカ テゴリー別の被覆率を図 13 に示す. 各カテゴリーからの顕熱を被 覆率の重み付け平均により合成して地表面境界条件とした。地表 面の熱収支式は，夜間を想定し放射，対流，伝導が釣合っている とした，対流熱伝達率はユルゲスの式で与え，パラメータとした 物性值は伝遒成分に関するものだけである．カテゴリー別の物性 值を表 2 に示す. 大気からの放射はブラントの式により与えた.

\section{2 ) 計算結果}

\begin{tabular}{l|llllll}
\multicolumn{6}{c}{ 表 2} & カテゴリー別の物性値 \\
\hline & \multicolumn{1}{|l}{ 植生 } & 裸地 & 水面 & 木造建物 & その他の建物 & 道路 \\
\hline 熱伝導率 $(\mathrm{W} / \mathrm{mK})$ & 1.05 & 1.05 & 0.57 & 1.05 & 1.7 & 0.7 \\
熱容量 $\left(* 10^{6} \mathrm{~J} / \mathrm{m}^{3} \mathrm{~K}\right)$ & 1.85 & 1.85 & 4.2 & 1.85 & 2.1 & 1.4 \\
\hline
\end{tabular}

計算結果の地表面温度分布, 顕熱フラックス分布, 地上 $1.5 \mathrm{~m}$ の 気温分布, 地上 $1.5 \mathrm{~m}$ の風分布を図 $14,15,16,17$ に示す. 顕熱フラッ クスは計算領域左下（南西）の市街地で正の值になっており，地 表面から空気へ熱が輸送されている. それに対し, 計算領域右上 （北東）の森林地域では負の值になり, 気温から地表面へ熱が輸送 されている. 顕熱の測定は行っていないため,ここでは定量的な 議論はできないが, 森林部で冷気が生成され市街地で混合されて いる様子が計算できていると考えられる．顕熱が計算領域内で正 と負の值を持っということは, 冷気流は地表面の条件によって泠 気を供給している場合（市街地に対して）と，逆に高温な熱を供 給している場合（森林部に対して）があることを指摘している. 


\section{4 標高分布を考慮した計算}

これまでは, 対象地域の市街地部分（計算領域南西側）はほぼ平 坦であると見なせたため，地形は全て平坦であるとして計算して いた。しかし実際は森林部分（計算領域北東側）には起伏があり その影響を考慮する必要があると考えられる。そこで，ここでは $50 \mathrm{~m}$ メッシュの標高データを組み込んだ計算を行い，地形が冷気流 による市街地気温分布に及ぼす影響について検討する．計算領域 内における地形の表現は，座標変換は行わず直交座標系で階段状 に与えるものとする．なお，その他の計算条件は前節と同じとす る。

計算結果の地表面温度分布, 顕熱フラックス分布, 地上 $1.5 \mathrm{~m}$ の 気温分布，地上 $1.5 \mathrm{~m}$ の風分布を図 $18,19,20,21$ に示す. 地表面温 度分布, 顕熱フラックス分布については, 標高分布を考慮しない場 合の計算結果（図 14,15）と比較して傾向はよく似ている，それに 対し，気温，風分布は標高分布を反映した結果となり，冷気が標高 の高い側から低い側へ流れ込み市街地内の気温が標高分布を考慮 しない場合と比較して低くなっている.

ただし，この計算では鈶直方向のメッシュ間隔を $3 \mathrm{~m} に$ 固定し標 高分布を階段状に与えているため, 標高差のある場所では計算領 域が急激に $3 \mathrm{~m}$ 分増堿する設定になっている. そのため, 計算結果 ではこのような傾斜のある場所において気流が収束, 発散してい る.実際の地形の勾配はスムーズなためこのような現象は生じず, この点は計算モデル上の課題である。地形に適合した座標系を用 いるなどの改善の余地はあるが，本研究では，地表面熱収支の考 虑, 標高分布の考慮, を計算モデルに組み込んだ場合の計算結果 に対する影響の考察を主眼に置いたため，上述のように課題は残 すものの，それぞれの効果について考察出来たと考えている.

\section{4. 結論}

本論文では，冷気流が流出してくる市街地内において，実測調查 と拡散モデルにより気温，風分布に関する検討を行い，冷気の流出 が市街地内の夜閒の熱環境に及ぼす影響について考察した。

1) 実測結果より，地上 $4.0 \mathrm{~m} ， 1.5 \mathrm{~m} の$ 気温及び地表面温度の観測 結果を比較すると，日射の蓄熱の影響で地表面温度がどの時間帯に おいても気温より高く保たれており，市街地一流入している冷気流 は文字通り市街地を冷却する能力を持っていると考えられる。

2 ) 実測結果の気温分布パターンは時間帯によってあまり変化せず, 川沿い地域において周辺市街地より常に低温である傾向であった。 川沿い地域では北風の風速が大きいことからも，冷気流が流れ込み やすく, 冷気流の流入に伴う気温低下の効果が大きく表れていると 考えられる.

$3)$ 計算結果は, 地表面温度分布の影響を受けて川沿いの地域に おいて気温が低下し，南部の密集市街地において高温となり，気
温分布の傾向は観測結果と比較的一致した. 計算結果の詨象領域 内での気温の幅はほぼ観測結果と一致した。

4) 風ベクトルの分布は, 地上 $1.5 \mathrm{~m}$ の観測結果は建築物等の障害 物による局所的な影響を受けているのに対し，計算結果はある程 度なめらかな粗度分布に応じた平均的な風べクトル分布になって いるため，十分に一致しているとは言えない，今後は，気温と同 様に局所的な影響を受けにくい高さでの測定法を検討する必要が あると考えられる。

5 ）土地利用別に地表面の熱収支を計算した結果, 顕熱が計算領 域内で正と負の值を持っため, 冷気流は地表面の条件によって冷 気を供給している場合（市街地に対して）と，逆に高温な熱を供 給している場合（森林部に対して）があることが示された．

6 ）標高分布を考虑した計算を行ったところ，市街地内の気温が 標高を考慮しない場合と比較して低くなった。このことは，地形 の勾配が冷気流の流下を促進し，市街地内の熱環境緩和効果を促 進する様子を表現していると考えられる。

謝辞 本研究を行うに当たり測定器を設置させて頂いた柊野小学校，紫竹 小学校の先生方に謝意を表します，また，本研究の一部を卒業論文として取 り組まれた和田ゆりか氏（TIS 侏)，森真传雄氏（奥村組）に謝意を表します。 本研究は地球環境財団研究奖励金（代表：竹林英樹）の補助を受けて行われ たものである

\section{参考文献}

1）竹林英樹, 森山正和, 系川文崇：夏季夜間における山麓冷気流の出現頻 度と市街地における影響距離, 日本建築学会計画系論文集, 第 542 号, pp. 99$104,2001.4$

2）竹林英樹，森山正和：夏季夜間における山麓冷気流の集積・流出過程に 関する研究，日本建築学会計画系論文集，第 558 号，pp. 57-61，2002.8 3）大橋唯太，泉岳樹，菅原広史，狩野真規，佐藤尚毅，一八瀨俊明，竹林 英樹：第 3 回独日都市気候シンポジウムの参加報告, 天気，48(3)，159-163, 2001.3

4) 数值流体力学編集委員会編：数值流体力学シリーズ 3 乱流解析, 東京大 学出版会, 1995

5) 加藤信介：数值流体力学 CFD の室内環境への応用 $(1) \sim(7)$, 空気調和 衛生工学, 第 71 巻第 $6 \sim 11$ 号, 第 72 巻第 1 号, $1997.6 \sim 11,1998$

6) 村上周三:CFDによる建築・都市の環境設計工学, 東京大学出版会, 2000 7 ) 佐々木澄, 持田灯, 吉野博, 渡辺浩文: 一都市内公園緑地の暑熱緩和効 果に関する研究（その2）-CFD 解析を用いた公園からの冷気流の流出とそ の熱的効果の検討, 日本建築学会大会学術講演梗概集, D-1, 903-904, 2001.9 8）大黒雅之, 村上周三，森川泰成，持田灯，足永靖信，大岡龍三，吉田伸 治，小野浩史：CFD を利用した屋外温熱空気環境設計手法に関する研究一川 風の温熱空気㻴境改善効果の解析一, 日本建築学会技術報告集, 第 16 号, $185-190,2002.12$

9) 近藤純正: 水環境の気象学一地表面の水収支・熱収支一, 朝倉書店, 1994 